\title{
EDITORIAL
}

\section{Primary Healthcare in the Post-COVID era: what can we expect?}

\author{
David Gaus[1] \\ 1. Andean Health \& Development - Estados Unidos \\ Doi: https://doi.org/10.23936/pfr.v6i2.204
}

RURAL FAMILY PRACTICE | Vol.6 | No.2 | Julio 2021 | Recibido: 29/07/2021 | Aprobado: 30/07/2021

\author{
How to cite this article \\ Gaus, D. Primary Healthcare in the Post-COVID era: what can we expect? Rural \\ Family Practice. 2021 July; 6 (2)
}

Compartir en:

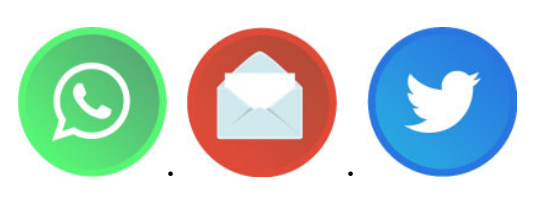

\begin{abstract}
COVID-19 has negatively impacted primary health care (PHC) activities globally. Some argue that now is the time, more than ever, to strengthen PHC in a postCOVID world. It could be argued that COVID-19 revealed the failures of PHC. Global aid agencies, starting with the World Bank, are already calling for the same technical solutions that, by themselves, have not addressed PHC failures in the past. A deeper understanding of the complexity of PHC failures might provide greater clarity to forge a path forward for PHC. Bourdieu's theory of fields might be a useful framework for that understanding.
\end{abstract}

Key words: primary healthcare, post-COVID, global health, Pierre Bourdieu.

\section{Atención Primaria en Salud en la era post-covid}

\section{Resumen}

La epidemia causada por el virus COVID-19 tiene un impacto negativo en la estrategia denominda Atención Primaria de Salud (APS) a nivel mundial. Se podría 
afirmar que el COVID-19 reveló las fallas de la APS. Técnicos especialista argumentan que es el momento de fortalecer la APS.

Las agencias de ayuda global, comenzando por el Banco Mundial, insisten en las viejas fórmulas técnicas que, por sí mismas, no han enfrentado las fallas de la APS en el pasado. Un entendimiento más profundo de la complejidad de las fallas de esta estrategia podría proporcionar una mayor claridad para forjar un camino a seguir para la APS. La teoría de campos de Bourdieu podría ser un marco útil para iniciar la deconstrucción de la fallida APS.

Palabras clave: atención primaria de salud, post-COVID, salud global, Pierre Bourdieu.

Primary Healthcare (PHC) services have been severely limited during the pandemic. The WHO reported that, globally, 1.4 million fewer people received care for tuberculosis in 2020 compared to 2019 - a reduction of 21\%.(1)_GAVI (Global Alliance for Vaccines and Immunization) supported vaccine campaigns were delayed by more than $50 \%$ in 2020 , potentially affecting the lives and wellness of millions of children. (2). COVID-19 disrupted critical mental health services in $93 \%$ of countries.(3).

These examples have been used to argue for the further reinforcement of PHC strategy. However, do they not also argue for the failure of PHC strategy?

PHC advocates seem unwilling to look closely at PHC limitations, yet these limitations are obvious - Health for All by 2020? - Millennium Development Goals? Of course, there are many successes of PHC, but the failures - and let's call them that - teach us many lessons. Among the most important of these lessons is that the failures are due largely to political and financial challenges, not technical challenges. Yet we continue to look for technical solutions for the failures of PHC. To be clear, technical solutions are part of the response, but by themselves, they achieve little.

The pandemic is another example of PHC looking for technical solutions without addressing political and financial constraints. In a recent World Bank Report, Walking the Talk: Reimagining Primary Health Care after COVID-19, the bank suggests the post-pandemic is a "once in a generation chance for a structural health system change."(4). However, their roadmap once again emphasizes technical solutions such as multidisciplinary teams, improved referral systems, digital platforms for integrated care, medical education reform, accreditation systems, and accountability, among others.(므).

Are we really going to recommend greater investment in "more of the same?" The famous quote, "the definition of insanity is doing the same thing over and over again and expecting different results," comes to mind.

A wiser approach to understanding how PHC should look, post-COVID, might include addressing the actual reasons for the failures of PHC - indeed a very uncomfortable topic for many health leaders around the globe. If done correctly, the complexity surrounding PHC failures would be revealed. One framework for a better understanding of that complexity might be through Bourdieu's concepts of field, which he defines as arenas of production, circulation, and appropriation and exchange of goods, services, knowledge, or status, and the competitive positions held by the actors in their struggle to accumulate, exchange, and monopolize different kinds of power resources (capital).(ㅁ).

Bourdieu's field could provide a framework to understand who the actors truly are - from within and outside the health sector. His theory could help define the actual capital that these actors are monopolizing, exchanging, struggling to accumulate, and fear losing. This sort of discussion would be a refreshing relief 
(and certainly unsettling) from the usual, ceaseless banter coming out of global aid and health policy agencies.

Bourdieu was neither a physician nor a public health expert. He was a sociologist, anthropologist, and philosopher. Are these not the disciplines required to understand how to think more clearly about PHC in the post-COVID era?

\section{Bibliographic references}

1. WHO Report. Impact of the COVID-19 pandemic on TB detection and mortality in 2020. https://www.who.int/publications/m/item/impact-of-the-covid-19-pandemic-on-tb-detection-and-mortalityin-2020. Accessed 29.7.21

2. Gavi. 30 June 2020: Overview of COVID-19 situation in Gavi-supported countries and Gavi's response. https://www.gavi.org/vaccineswork/30-june-2020-overview-covid-19-situation-gavi-supported-countriesgavi-response. Accessed 29.7.21

3. WHO Report. COVID-19 disrupting mental health services in most countries. https://www.who.int/news/item/05-10-2020-covid-19-disrupting-mental-health-services-in-most-countrieswho-survey. Accessed 29.7.21

4. "World Bank. 2021. Walking the Talk : Reimagining Primary Health Care After COVID-19. World Bank, Washington, DC. (C) World Bank. https://openknowledge.worldbank.org/handle/10986/35842 License: CC BY 3.0 IGO."

5. World Bank. 2021

6. Swartz D. Bourdieu's Concept of Field. Oxford Bibliographies. https://www.oxfordbibliographies.com/view/document/obo-9780199756384/obo-9780199756384-0164.xml accessed 29.7.21 